\title{
A Complicated Neurological Case in the Emergency Department: Concomitant Guillan-Barre Syndrome, Meningitis and Spinal Astrocytoma
}

\author{
Acil Servise Gelen Komplike Bir Nöroloji Olgusu: Eş zamanlı Gullian-Barre \\ Sendromu, Menenjit ve Spinal Astrositom
}

Selman Yeniocak', Asım Kalkan², Süha Türkmen³

'Emergency Department, Haseki Training And Research Hospital, İstanbul, Turkey

2Department of Emergency Medicine, Recep Tayyip Erdogan University School of Medicine, Rize, Turkey

${ }^{3}$ Department of Emergency Medicine, Karadeniz Technical University Faculty of Medicine, Trabzon, Turkey

\section{ABSTRACT}

Introduction: Patients presenting at the emergency department with a range of complaints are likely to have a diagnosis of more than one disease. These patients with more than one system involvement, who will receive a diagnosis of concomitant diseases, cause various difficulties for emergency department physicians.

Case Report:The case is presented here of a 28-year old male who presented at the emergency department with clinical findings of Guillan-Barre Syndrome, meningitis and spinal astrocytoma following an upper respiratory tract infection.

Conclusion: This paper aimed to discuss the diagnoses, followup and treatment of this rare disease patient who has presented with clinical findings of GBS and who was then diagnosed of concomitant GBS, meningitis and spinal astrocytoma.

Keywords: Concomitant disease, difficulties, Guillan-Barre Syndrome, Meningitis, Astrocytoma

Received: 11.09.2012 Accepted:09.04.2013

\section{ÖZET}

Giriş: Acil servise çeşitli şikayetlerle müracaat eden hastalar eşzamanlı olarak birden fazla hastalık tanısı alması olasıdır. Bir ve birden fazla sistemi ilgilendiren eşzamanlı hastalık tanısı alabilecek hastalar, acil hekimine çeşitli zorluklar yaşatabilir.

Olgu Sunumu: Yirmi sekiz yaşında erkek hasta geçirdiği üst solunum yolu enfeksiyonu sonrasında eşzamanlı Guillain-Barre Sendromu, menenjit ve spinal astrositom klinik bulguları ile acil servisimize müracaat etti.

Sonuç: Bu yazda GBS klinik bulguları ile başvuran, GBS, menenjit ve spinal astrositom tanısı alan nadir bir olgunun tanı ve tedavisini tartışmayı amaçladık.

Anahtar Kelimeler: Eş zamanlı hastalık, zorluk, Guillan-Barre Sendromu, Menenjit, Astrositom

Geliş Tarihi: 11.09.2012 Kabul Tarihi: 09.04.2013

\section{Introduction}

Acute or subacute Guillan-Barre Syndrome (GBS) is an inflammatory demyelinating disease characterized by progressive flask paralysis (1). Meningitis, which is caused by various microorganisms, is an inflammatory disease with acute or chronic onset, which damages the brain membranes and brain tissues and is characterized by cerebral spinal fluid cellular and biochemical changes and clinical neurological findings (2). Astrocytomas are intradural-intramedullar tumours which make up 5\% of all spinal tumours (3). This paper aimed to discuss the diagnoses, follow-up and treatment of this rare disease patient who has presented with clinical findings of GBS and who was then diagnosed of concomitant GBS, meningitis and spinal astrocytoma. 


\section{Case Report}

A 28-year old male patient presented at the emergency department with complaints of head and neck pain, numbness of the hands and loss of strength in the feet. A previous history of upper respiratory tract infection was present 3 weeks ago. Medical history revealed nothing to was normal. On presentation, his Glasgow Coma Score (GCS) was 14 (E3V5M6). Arterial blood pressure was 150/100mmHg, pulse rate $102 / \mathrm{bpm}$, respiratory rate $20 / \mathrm{min}$ and fever $38^{\circ} \mathrm{C}$. Physical examination determined mydriasis and ptosis in the right eye and no light reflex in the right eye. There was right central facial paralysis and stiffness of the neck. The Babinski reflex was negative on both sides and the deep tendon reflexes (DTR) was reduced bilaterally in all extremity. There was a two fifths loss of strength in the lower extremities. The sphincter tone was on decrease. The laboratory values were measured as glucose $136 \mathrm{mg} / \mathrm{dL}$ (70-110mg/dL), CRP 36.90 mg/dL (0-0.5 mg/dL), LDH 1155 U/L (240-480 U/L), CK-MB $69 \mathrm{U} / \mathrm{L}(0-6.73 \mathrm{U} / \mathrm{L})$, leukocyte count $20.500 / \mathrm{mm}^{3}\left(4.8-10.8 / \mathrm{mm}^{3}\right)$, sedimentation rate $74 / \mathrm{hrs}(0-20 / \mathrm{hrs})$ and procalcitonin $2.09 \mathrm{ng} / \mathrm{mL}$ (0-0.5ng/mL). The other laboratory tests was normal.

No pathology was reported on the CT of the brain. On the microscopic evaluation of the cerebrospinal fluid (CSF) drawn by an LP, gram staining did not reveal any cells and microorganism. Biochemical analysis of CSF determined glucose $1 \mathrm{mg} / \mathrm{dL}$ and protein $>175 \mathrm{mg} / \mathrm{dL}$. Electromyography and MRI of brain were reported as normal. Patient diagnosed as meningitis and treatment intravenous ceftriaxone 2 gram/day and amphotericin-B 1 gram/day was started. On the second day of treatment, the patient was intubated and admitted to the intensive care unit since oxygen saturation was decreased and respiratory problems developed. After two months in intensive care unit, he was still having difficulty in swallowing, had facial asymmetry, loss of sensation in upper extremities bilaterally and paraplegia, therefore, sequels of meningitis was assumed to be developed.

After the planning of rehabilitation with Physical Medicine and Rehabilitation (PMR), he was discharged with partial recovery. Despite 6 months of PMR support to the treatment, no improvement was observed in the patient's condition, so, an MRI of the spine was ordered. An intradural-intramedullar mass was shown from T3 through T9 (Figure 1). An astrocytoma was diagnosed with a biopsy so the patient was readmitted and a T4-T5-T6 total laminectomy was performed and then he was discharged. Unfortunately, no improvement in the findings were observed, the patient readmitted one month later. Patient eveluated again. After several work-ups including an EMG, the patient was diagnosed as Bickerstaff's brain stem encephalitis, a variant of GBS and treatment of intravenous immunoglobulin (IVIG) was started. After IVIG, loss of sensation was ceased, muscular strength was increased and the patient became able to stand with support.

\section{Discussion}

In $60-70 \%$ of GBS cases, there is a history of infection 1-4 weeks previously before the onset of neurological symptoms. Generally the

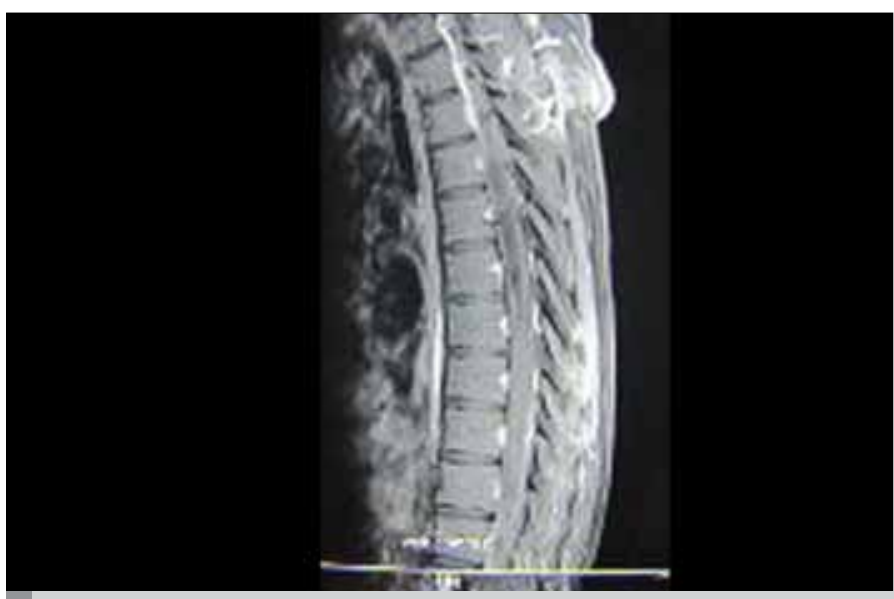

Figure 1. Spinal astrositom

first clinical sign is the development of muscle weakness, starting from the lower extremities and progressing upwards (Landry's ascending paralysis). Due to the ascending progressive muscle weakness, respiratory impairment can develop associated with the involvement of the intercostal muscles. DTR decrease or may disappear completely (4). As there are many known variants, clinical similarities to meningitis may be seen as in the case presented here and this may cause delayed diagnosis.

LP findings are important for the diagnosis of meningitis. But, despite a diagnosis of bacterial meningitis, $12 \%$ of cases, as in our case, may not have pathological LP findings and in the diagnosis of these cases can be only based on clinical findings (5). However, diagnosis of GBS depends on history and clinical findings as an immune-mediated disease of the peripheral nervous system, characterized by progressive muscle weakness and loss of reflexes within days. Typical clinical findings of GBS are mild paresthesis in the fingertips, followed by symmetrical weakness in the lower extremities and hours or days later, involvement of the upper extremities and respiratory muscles. Pain occurring particularly in the back, the lower extremities and the abdominal region, is one of the definitive characteristics of the syndrome (6).

Although EMG is useful for diagnosis, it should not be forgotten that in the first few days of the disease all the nerve conduction test results may be normal, as in the case presented here (7). In Bickerstaff's brain stem encephalitis, one of the variants of GBS, there are changes in consciousness, ataxia and symmetrical opthalmoplegia. The Babinbski reflex has been reported that could be positive in 50\% of cases (8). Due to the potential fatal complications of GBS, close monitoring is required. Plasmapherisis and IVIG have been found to be effective particularly in the first two weeks of treatment. Plasmapherisis should be applied a total of five times during two weeks. IVIG at a dose of $0.4 \mathrm{gr} /$ $\mathrm{kg}$ should be applied for five days. No advantage of the concomitant use of IVIG and plasmapherisis was shown in the application (9).

Astrocytomas are most frequently seen in the third and fourth decade of life. More than half of spinal cord astrocytomas are 
observed particularly in the upper thoracic region. They may cause sphincter impairment and segmental lower motor neuron findings (3). The presence of astrocytoma in the case presented here was incidental and increased the difficulty of diagnosis.

In our case, fever, stiffness of the neck, increasing neck and head pain, altered mental status, results of the CSF analysis, increase in the acute-phase reactants and laboratory findings of infection led to the diagnosis of meningitis. Alterations in mental status may be present in meningitis and more than $95 \%$ of adult cases have stiffness of the neck. Kernig and Brudzinski signs indicate meningeal irritation with 95\% specificity and 5\% sensitivity (10).

Despite low glucose levels in CSF analysis indicating bacterial meningitis, no cells were present, so, diagnosis of meningitis was made according to clinical findings and empirical Ab Tx was initiated. The involvement of N.oculomotorius and N.facialis in this case from the history of upper respiratory tract infection, followed by progressive motor loss ascending from the lower extremities, the loss of feeling in the hands, that these findings were symmetrical, areflexia and DTR loss led to consideration of GBS. However, that no pathology was determined from the EMG which examined 3 days after the onset of symptoms, caused a distancing from the GBS diagnosis and the neurological condition was thought to be associated with meningitis and so a late diagnosis was made of this variant type.

In this presentation, it is tried to be emphasized that the emergency phyicians should take into consideration the concomitant diagnosis of the disease that has one or more than one system involvement on some patients. Moreover, they should remember GBS and its variants if there are extraordinary presences. It is also tried to be explained that the cases may be concomitantly complicated.

Informed Consent: Written informed consent was obtained from the patient who participated in this study.

Peer-review: Externally peer-reviewed.

Author Contributions: Concept - A.K, S.Y.; Design - A.K.; Supervision - S.Y.; Materials - S.Y.; Data Collection and/or Processing - S.Y.; Analysis and/or Interpretation - S.T.; Literature Review - A.K, S.T.; Writer - A.K.; Critical Review - S.T, S.Y.

Conflict of Interest: The authors declared no conflict of interest.

Financial Disclosure: The authors declared that this study has received no financial support.
Hasta Onamı: Yazılı hasta onamı bu çalışmaya katılan hastadan alınmıştır

Hakem Değerlendirmesi: Dış bağımsız.

Yazar Katkıları: Fikir - A.K, S.Y.; Tasarım - A.K.; Denetleme - S.Y.; Malzemeler - S.Y.; Veri toplanması ve/veya işlemesi - S.Y.; Analiz ve/ veya yorum - S.T.; Literatür taraması - A.K, S.T.; Yazıyı yazan - A.K.; Eleştirel İnceleme - S.T., S.Y.

Çıkar Çatışması: Yazarlar herhangi bir çıkar çatışması bildirmemişlerdir.

Finansal Destek: Yazarlar bu çalışma için finansal destek almadıklarını beyan etmişlerdir.

\section{References}

1. Ropper AH. The Guillain-Barré syndrome. N Engl J Med 1992; 326: 1130. [CrossRef]

2. Edmond K, ClarkA, KorczakVS, Sanderson C, Griffiths UK, Rudan I. Global and regional risk of disabling sequelae from bacterial meningitis: a systematic review and meta-analysis. Lancet Infect Dis 2010; 10: 317-28. [CrossRef]

3. Ciappetta P, Salvati M, Capoccia G, Artico M, Raco A, Fortuna A. Spinal glioblastomas: report of seven cases and review of the literature. Neurosurgery 1991; 28: 302-6. [CrossRef]

4. Jacobs BC, Rothbarth PH, van der Meché FG, Herbrink P, Schmitz PI, de Klerk MA, et al. The spectrum of antecedent infections in Guillain-Barré syndrome. A case-control study. Neurology 1998; 51: 1110-5. [CrossRef]

5. Fitch MT, van de Beek D. Emergency diagnosis and treatment of adult meningitis. Lancet Infect Dis 2007; 7: 191-200. [CrossRef]

6. The French Cooperative Group on Plasma Exchange in Guillain-Barre Syndrome. Efficiency of plasma exchange in Guillain-Barré Sydrome: role of replacement fluids. Ann Neurol 1987; 22: 753-61. [CrossRef]

7. Ropper AH, Wijdicks EFM, Shahani BT. Electrodiagnostic abnormalities in 113 patients with Guillain-Barre syndrome. Arch Neurol 1990; 47: 881-7. [CrossRef]

8. Yuki N. Fisher syndrome and Bickerstaff brainstem encephalitis (FisherBickerstaff syndrome). J Neuroimmunol 2009; 215: 1-9. [CrossRef]

9. Van Doorn PA, Ruts L, Jacobs BC. Clinical features, pathogenesis, and treatment of Guillain-Barré syndrome. Lancet Neurol 2008; 7: 939-50. [CrossRef]

10. Tunkel AR, Scheld WM. Acute meningitis. In: Mandell GL, Douglas RG, Bennett JE, eds. Mandell, Douglas and Bennett's Principles and Practice of Infectious Diseases. $6^{\text {th }}$ ed. New York: Churchill Livingstone; 2005. p.1083-126. 